\title{
Filmowa franczyza. Od tematu do widowiska telewizyjnego (na podstawie cyklu „Prawdziwe Historie”)
}

\begin{abstract}
Aвstract. Otto Wojciech, Filmowa franczyza. Od tematu do widowiska telewizyjnego (na podstawie cyklu „Prawdziwe Historie”) [Film franchise. From the theme to the TV show (based on the True Stories [Prawdziwe Historie] series)]. „Images” vol. XXVI, no 35. Poznań 2019. Adam Mickiewicz University Press. Pp. 159-170. ISSN 1731-450X. DOI 10.14746/i.2019.35.09.

The TV series True Stories (Prawdziwe Historie) is an example of contemporary commercial cinema. It is located on the border of documentary film and an attractive version of fictional cinema. In specific circumstances, it can be treated as a commercial product, but not only in the sense of film production and distribution, but more broadly, as a recognisable brand on the domestic cinema market, containing all the elements of industry know-how, as well as significant and commonly seen features of a film style that guarantees both turnout and financial success. In a sense, therefore, this phenomenon can be considered in terms of a film franchise which offers creators, most often beginners, a proven business patent in the form of a coherent television series, but also giving the possibility of a safe feature debut and the space for creative exploration.
\end{abstract}

KEYWORDS: film, franchise, popular cinema, film fiction, true stories

Cykl telewizyjny „Prawdziwe Historie” wyprodukowała stacja telewizyjna TVN. Premiera nastąpiła 30 września 2010 roku w kanale TVN filmem pt. Krzysztof w reżyserii Dariusza Twaroga. W skład serii weszły ponadto: Cisza Sławomira Pstronga (2010), Laura Radosława Dunaszewskiego (2010), które miały swoje premiery na szklanym ekranie, oraz Bokser Tomasza Blachnickiego (2012), Nad życie (2012) Anny Pluteckiej-Mesjasz i Mój biegun Marcina Głowackiego (2013), które zaistniały na festiwalach, między innymi w Gdyni i w Koszalinie. Cykl reklamowano jako „opowieści o zwykłych ludziach postawionych wobec niezwykłych wyzwań, którymi w ostatnich latach żyła cała Polska. Historie inspirowane życiem, bez zbędnego patosu i sztucznego happy endu, ale $\mathrm{z}$ optymistycznym przesłaniem" $[1]$.

Punktem wyjścia dla realizatorów stał się zatem nośny temat, pewien fakt społeczny, nagłośniony medialnie i przyswojony przez szeroką rzeszę odbiorców. „Wybieraliśmy je z dużą rozwagą - konstatuje Krystyna Lasoń, producentka cyklu - bowiem nie z każdej, budzącej zainteresowanie opinii publicznej, sprawy można zrobić film niosący pewien morał. Nie każda $\mathrm{z}$ historii daje się przetworzyć tak, aby nie

[1] Cytat z oficjalnej strony cyklu „Prawdziwe Historie", <https://www.tvn.pl/aktualnosci/prawdziwe- -historie-oficjalna-strona-stacji-tvn,238988,n.html> [dostęp: 12.04.2019]. 
być dosłownością, a jednocześnie zachować swą wiarygodność" [2]. W pierwszym skojarzeniu takie działanie przywołuje jedną z najstarszych filmowych tradycji, wywodzącą się z praktyki twórczej Georges'a Mélièsa, który w zaciszu swojego atelier realizował rekonstrukcje dokumentalne ważnych, aktualnych i niezwykle popularnych wydarzeń medialnych, szeroko komentowanych na pierwszych stronach gazet (na przykład Sprawa Dreyfusa). Tradycje „starego" kina sprawdzają się $\mathrm{w}$ tym przypadku zarówno w kwestii polityki odbioru i kształtowania preferencji widzów, jak i szeroko rozumianej estetyki dzieł.

Tak rozumiane dzieło filmowe należy rozpatrywać w kategoriach pewnego rynkowego produktu, który spełnia określone wymagania estetyczne, uwarunkowane specyfiką telewizyjnej serii oraz założonym a priori profilem odbiorcy. Konstytutywny w tym zestawieniu jest oczywiście podjęty przez realizatorów temat, czyli powszechnie znana i szeroko komentowana na forum publicznym prawdziwa historia z udziałem autentycznych postaci, stanowiąca zarzewie i oś filmowej fabuły. Nie bez znaczenia pozostają również kwestie estetyczne, czyli wszelkie zabiegi narracyjne i stylistyczne, zaświadczające o spójności filmowego cyklu i projektujące zakres oraz profil grup odbiorczych.

Podobne inicjatywy pojawiały się już kilkukrotnie w przeszłości, głównie za sprawą Telewizji Polskiej. Dość wspomnieć cykl czarno-białych filmów krótkometrażowych, zrealizowanych w latach 1967-1968 przez Zespół Filmowy „Studio”, pod wspólną nazwą „Opowieści Niezwykłe" czy dziewięcioodcinkowy cykl telewizyjnych filmów fabularnych „Najważniejszy Dzień Życia”, firmowany przez Zespół Filmowy "Iluzjon” (rok 1974). Najciekawszym jednak przedsięwzięciem była kilkunastoodcinkowa seria telewizyjna zatytułowana "Święta Polskie" (lata 2000-2007), której sygnatariuszami byli uznani reżyserzy filmowi, między innymi Izabella Cywińska, Janusz Morgenstern, Ryszard Bugajski, Janusz Kondratiuk, Andrzej Barański, Robert Gliński i Radosław Piwowarski. Każdy z powyższych cykli miał wyróżniający go element sprawczy. W pierwszym przypadku był nim gatunek - kino grozy, w drugim luźna formuła kina obyczajowego, zdeterminowana przez tytułowy motyw fabularny, w trzecim kontekst społeczno-kulturowy, odnoszący poszczególne tytuły filmowe do świąt kalendarzowych obchodzonych w Polsce, na przykład Dnia Ojca, Walentynek, Bożego Ciała itd. „Opowieści Niezwykłe” to zamknięta seria pięciu krótkich filmów, których cechą wspólną jest atmosfera tytułowej „niezwykłości”, tajemniczości, uzyskana poprzez ukazywanie duchów osób nieżyjących czy personifikacji śmierci. Niektóre z filmów pod względem gatunkowym ocierają się o kino grozy, inne przypominają bardziej film sensacyjny, jeszcze inne mają lżejszą, niemal komediową tonację[3]. Historie zawarte w cyklu „Najważniejszy Dzień Życia” łączy tematyka obyczajowa, dotycząca absurdów rzeczywistości PRL-u lub odnoszą-

[2] Ibidem.

[3] Zob. <https://pl.wikipedia.org/wiki/ Opowie\%C5\%9Bci_niezwyk\%C5\%82e> [dostęp: 28.04.2019]. 
ca się do społecznych obserwacji rodem z telewizyjnego reportażu. $\mathrm{Na}$ tym tle najambitniejszym przedsięwzięciem okazał się cykl firmowany godłem Telewizji Polskiej, zatytułowany „Święta Polskie”. Podejmował pogłębioną tematykę psychologiczną i moralną w odniesieniu do rodzimej tradycji i obyczaju, nierzadko z dużą dozą komizmu, w którym na tle świątecznych rytuałów ujawniały się postawy i poglądy współczesnych Polaków.

Cykl „Prawdziwe Historie” wyróżnia na tle opisanych powyżej jasno określony i sprofilowany odbiorca oraz niezwykle skonwencjonalizowana i powtarzalna we wszystkich częściach stylistyka. Jakie są tego przyczyny? Wydaje się, że najistotniejszą determinantą takiego stanu rzeczy jest fakt, iż został on wyprodukowany przez prywatną stację telewizyjną TVN. W założeniach jej twórców miała stać się komercyjną alternatywą dla telewizji publicznej, gwarantując nowoczesność, niezależność i otwarcie na masowego odbiorcę. Począwszy od roku 1997, czyli daty pierwszej emisji, TVN prowadziła konsekwentną politykę programową, serwując widzom dynamiczne przekazy informacyjne (Fakty TVN), atrakcyjne programy rozrywkowe, nierzadko wcześniej sprawdzone na zachodnim czy amerykańskim rynku (Milionerzy, Taniec z gwiazdami), oraz nowoczesne seriale i filmy z kręgu kina gatunkowego, hollywoodzkiego czy mainstreamowego. Na przestrzeni lat stacja wypracowała stricte komercyjny charakter, bez ambicji emitowania programów misyjnych, kierując się przede wszystkim statystykami oglądalności i popularnością wśród jak najszerszej rzeszy odbiorców.

Decyzje programowe $\mathrm{w}$ dużej mierze uzależniano od zapotrzebowania sygnalizowanego przez rynek mediów i samych widzów. Cykl „Prawdziwe Historie” powstał na fali popularności programów typu reality show oraz wszelkich odmian kina dokumentalnego i paradokumentalnego. Tradycja ta była niezwykle bogata, począwszy od fabularyzowanych dokumentów historycznych (inscenizowana „Rewizja Nadzwyczajna” Dariusza Baliszewskiego czy „Sensacje XX Wieku” Bogusława Wołoszańskiego) i seriali historycznych opartych na faktach (Tajemnica twierdzy szyfrów Adka Drabińskiego), przez programy telewizyjne o pracy policji, prezentujące interwencje funkcjonariuszy na gorąco, i seriale sensacyjno-kryminalne realizowane w poetyce fabularyzowanego dokumentu, tak zwane docu-crime ( $W$-11. Wydział śledczy Jacka Januszyka), na fabułach opartych na faktach (cykl TVP „Okruchy Życia”) i filmach biograficznych inspirowanych przełomowymi wydarzeniami (JFK Olivera Stone’a) skończywszy.

Skąd zatem pomysł? Co zaważyło na tym, że filmy te wyprodukowała komercyjna stacja telewizyjna? Liczono przede wszystkim na sukces finansowy i zainteresowanie widzów, gwarantem tego miał być nośny temat - znane sprawy i zdarzenia, nagłośnione medialnie, czasem tajemnicze i nierzadko niewyjaśnione do dziś, oraz wspólna i uspójniająca cykl poetyka tych filmów, osadzona głęboko w stylistyce kina popularnego. Gdyby sięgnąć do nomenklatury ekonomii i biznesu, co w przypadku tego typu kina jest jak najbardziej uprawnione, po- 
szczególne tytuły filmowe można by opatrzyć nadrzędnym terminem filmowej franczyzy, czyli komercyjnego przedsięwzięcia firmowanego wspólną nazwą („Prawdziwe Historie”), rozpoznawalnym logo (jednakowa dla wszystkich części czołówka z muzyką Krzysztofa Preisnera[4]) i atrakcyjną ofertą w postaci telewizyjnych, pełnometrażowych filmów fabularnych, zrealizowanych w założonej $a$ priori poetyce i adresowanych do masowego odbiorcy [5]. Oczywiście, porównanie to jest rodzajem skrótu myślowego i wskazaniem na pewną analogię mechanizmów funkcjonowania dzieła filmowego na branżowym rynku ze specyfiką franczyzy jako takiej. Trzeba przy tym zaznaczyć, że istotną rolę w tym zestawieniu odgrywa nie tylko proces produkcji i dystrybucji filmu, ale także, a może i przede wszystkim, wymiar artystyczny dzieła filmowego, ujawniający się na płaszczyźnie formalnej.

Wszystkie filmowe odsłony „Prawdziwych Historii” zostały zrealizowane $\mathrm{w}$ podobnej stylistyce, $\mathrm{z}$ wykorzystaniem tych samych środków wyrazu i z myślą o tym samym odbiorcy. Warto przyjrzeć się bliżej przynajmniej trzem $\mathrm{z}$ nich, tym, które otwierały cykl w roku 2010. Są to: Krzysztof Dariusza Twaroga, Cisza Sławomira Pstronga oraz Laura Radosława Dunaszewskiego.

Już z pobieżnej analizy faktów wynika, że filmy te, mimo pewnych rozbieżności genologicznych, bardzo wiele łączy. Wszystkie zamykają się w formule telewizyjnego długiego metrażu, wszystkie zostały wyreżyserowane przez debiutantów, którzy wcześniej współpracowali ze stacją TVN przy produkcjach telenoweli, seriali telewizyjnych i programów z gatunku docu-crime. Doświadczenia te z pewnością odcisnęły wyraźne piętno na kształcie artystycznym wspomnianych tytułów filmowych. I rzecz najistotniejsza - scenariusze tych produkcji powstały na podstawie autentycznych zdarzeń, tytułowych prawdziwych historii, dramatycznych i nagłośnionych medialnie, dla których materia filmowa stała się najbardziej efektownym i efektywnym sposobem na osiągnięcie sukcesu frekwencyjnego. I tak Krzysztof to historia brutalnego porwania i zabójstwa syna znanego przedsiębiorcy z Dobrzynia - Włodzimierza Olewnika. Pokazana z perspektywy jego siostry Doroty, która prowadzi heroiczną walkę z ludzką bezwzględnością. Cisza opowiada dramatyczną historię uczniów z tyskiego liceum, którzy zginęli pod lawiną podczas wycieczki szkolnej w Tatry. Laura natomiast to fabularna rekonstrukcja tragicznych wydarzeń z lutego 2006 roku w kopalni Halemba, w której po niekontrolowanym tąpnięciu pod ziemią został uwięziony jeden z górników, ostatecznie szczęśliwie uratowany po czterech dniach dramatycznej walki o przetrwanie.

Jak zatem widać, wykorzystane w filmach historie same w sobie mają ogromny medialny potencjał, gwarantujący im żywe zaintereso-

[4] Twórcami czołówki byli: Robert Halastra i Jarek Migoń.

[5] Franczyza to rodzaj współpracy między niezależnymi przedsiębiorcami. Franczyzodawca udostępnia swoje „know-how” oraz markę, ale w zamian pobiera opłatę od franczyzobiorcy, który może korzystać ze sprawdzonego pomysłu na biznes. Zob. <https://franchising.pl/abc-franczyzy/> [dostęp: 10.04.2019]. 
wanie odbiorców oraz niezwykle emocjonalny przekaz. Nie bez znaczenia jest fakt, że wśród poruszanych tematów znalazły się porwania, afery polityczne, włącznie z sejmową komisją śledczą, czy niezawinione ludzkie tragedie, nierzadko $\mathrm{z}$ udziałem niewinnych dzieci[6]. Co interesujące, ekranowe wersje powyższych wydarzeń często uzyskują wymiar jedynej i obowiązującej prawdy, mimo że z ową prawdą niekiedy niewiele mają wspólnego. Autorzy poszczególnych części cyklu, co oczywiste, nie rościli sobie prawa do wiernego dokumentowania faktów, wręcz przeciwnie, nadrzędnym założeniem było pozostawienie w scenariuszu tylko tych autentycznych zdarzeń, które bezpośrednio odwoływały się do znanych z przekazów medialnych faktów i które widz mógł bez problemu powiązać z rzeczywistością pozaekranową. Pozostałe elementy fabuły oraz rozwiązania inscenizacyjne służyły przede wszystkim uatrakcyjnieniu widowiska filmowego. Wymownym na to dowodem są zakończenia omawianych filmów. W Krzysztofie w napisach końcowych pojawia się czarna plansza informacyjna: „Na potrzeby filmu część postaci, nazwisk i faktów została zmieniona”. W filmie Cisza oprócz napisu końcowego („28 stycznia 2003 roku w lawinie pod Rysami zginęło ośmioro uczestników wycieczki szkolnej z liceum w Tychach. Film dedykujemy ich pamięci”) autorzy zamieścili fotografie autentycznych uczestników wycieczki wraz z ich prawdziwymi imionami, natomiast $\mathrm{w}$ Laurze podobną funkcję pełni finalny napis: „9 miesięcy później, 21 listopada 2006 roku, na Halembie zginęło 23 górników. Zbyszek tego dnia pracował na innej zmianie". Każde z tych rozwiązań kierunkuje uwagę widza w nieco inne obszary. W pierwszym posłużono się standardową formułą stosowaną w filmach opartych na faktach, w drugim zdecydowanie bardziej zaakcentowano związek filmu $\mathrm{z}$ rzeczywistością pozaekranową, $\mathrm{w}$ trzecim natomiast akcent został przeniesiony z historii głównego bohatera (Zbyszka Nowaka) na inne tragiczne zdarzenie, które miało miejsce w tej samej kopalni kilka miesięcy później, co w pewnym sensie nadało opowiadanej historii uniwersalny wymiar.

Relacje prawdy i fikcji w całym filmowym cyklu przedstawiają się niezwykle interesująco i stanowią wymowny przykład intertekstualnej gry między naturą faktów a ekranowym światem fikcjonalnym. W każdym z omawianych filmów odchylenia i odstępstwa od życiowej prawdy wynikają w dużej mierze ze specyfiki samego medium filmowego, które operuje skrótem, kondensacją zdarzeń oraz potrzebą budowania konfliktów i wywoływania emocji. Nie bez znaczenia są również ograniczenia budżetowe i logistyczne. Mimo wszystko jednak wszystkie te historie różnią się w jakimś stopniu od siebie. Dotyczą bowiem odmiennych zdarzeń, odmiennych bohaterów i zróżnicowanej czasoprzestrzeni. Najważniejsze pytanie, na jakie musieli odpowiedzieć sobie twórcy tych filmów, dotyczyło tego, co z autentycznej historii

[6] W kolejnych częściach cyklu pojawiła się dodatkowa atrakcja - znane i popularne postaci: podróżnik
Jan Mela, bokser Przemysław Saleta czy sportsmenka Agata Mróz. 
pozostawić w scenariuszu i jak ująć ją na ekranie. W tym działaniu spotykały się dwie wykluczające się wzajemnie tendencje: konieczność odtworzenia prawdziwych zdarzeń z jednej strony, z drugiej - zbudowanie atrakcyjnego widowiska filmowego, opierającego się na środkach wyrazowych kina fikcjonalnego (bo to w końcu film fabularny), we wspólnej i założonej a priori dla wszystkich części cyklu stylistyce, bliskiej masowemu odbiorcy, czyli kojarzonej z komercyjną z natury kulturą popularną.

Na płaszczyźnie fabuły rzecz przedstawia się następująco. W filmie Dariusza Twaroga największe wyzwanie stanowiła ilość wątków i zdarzeń, które tworzyły całą historię. Reżyser, siłą rzeczy, musiał je ograniczyć i wyeksponować te, które składały się na jego wizję przedstawianej historii. Wydaje się, że zaważyły na niej dwie istotne okoliczności: sprawa porwania Krzysztofa Olewnika praktycznie nigdy nie została do końca wyjaśniona, po drugie - ekranowa historia nie mogła być zbyt złożona i zagmatwana, ponieważ byłaby nużąca, nieczytelna i trudna w odbiorze dla niewymagającego odbiorcy. Wymagało to od reżysera umiejętności wprawnego balansowania między ekranową fikcją a dostępną mu sumą faktów, podejrzeń i insynuacji, zapożyczoną głównie przez media. Jednym z najprostszych chwytów było wprowadzenie imion i nazwisk bohaterów, sugerujących wyraźne konotacje $z$ autentycznymi osobami: w filmie Władysław i Dorota Orłowiczowie, w rzeczywistości Włodzimierz i Danuta Olewnikowie, oczywiście tytułowe imię Krzysztof oraz nazwa miejscowości, w której dzieje się akcja: w filmie Dobrzyń, w rzeczywistości Drobin. Na płaszczyźnie fabuły dobór wątków i motywów uzależniono od kilku czynników, które gwarantowały prawdopodobieństwo zdarzeń, przejrzystość narracji oraz atrakcyjność opowiadanej historii. Twórcy nie trzymali się sztywno faktografii ani zgodności czasoprzestrzennej, nie przywiązywali również wagi do wiernego odtwarzania szczegółów, zdecydowanie ważniejszą rolę odgrywały względy dramaturgiczne. Nie znaczy to jednak, że sprzeniewierzali się prawdzie. Historia porwania i śmierci Krzysztofa Olewnika prezentuje się na ekranie w sposób spójny i przekonujący. Nie pominięto żadnych istotnych faktów, nie wykluczono także nikogo $\mathrm{z}$ ważniejszych bohaterów. W filmie znalazły swoje potwierdzenie wszystkie zdarzenia, począwszy od samego porwania Krzysztofa Olewnika, przez walkę rodziny o jego odzyskanie (zatrudnienie znanego detektywa, przekazanie okupu, wciągnięcie w sprawę prokuratora z Olsztyna), po sejmową komisję śledczą. Zachowano w ten sposób węzłowe punkty całej historii, natomiast znacząco zmieniono niektóre okoliczności im towarzyszące oraz nieco inaczej rozmieszczono akcenty. Ambicją reżysera było odtworzenie zdarzeń w materii filmowej i zdemaskowanie sprawców, jednak, by widowisko uczynić bardziej spektakularnym, pokusił się również o pewne aluzje natury politycznej, sugerując korupcję policji oraz udział w sprawie wysoko postawionych urzędników państwowych, o czym niejednokrotnie spekulowały media. Wprowadził ponadto nowe wątki natury obyczajowej, 
tym razem zupełnie zmyślone, na przykład rywalizację i konflikt między siostrami Krzysztofa Olewnika, które wynikały z faworyzowania jednej z nich przez ojca, a także elementy życia osobistego jednego z porywaczy, odsłaniające ludzką twarz zbrodniarza, kochającego męża i ojca.

Takie same twórcze zamierzenia przyświecały autorom dwóch pozostałych filmów cyklu. W Ciszy, by sprostać powinnościom tematologicznym i faktograficznym, reżyser $z$ dużą dozą skrupulatności zachował czas i miejsce akcji: 28 stycznia 2003 roku - zejście lawiny pod Rysami, akcja ratunkowa TOPR, hospitalizacja w szpitalu w Zakopanem oraz przygotowania do wyprawy w Tychach i przeżywanie żałoby przez rodziców, rodzeństwo i przyjaciół. Odtworzył ponadto węzłowe punkty zdarzeń dotyczące organizacji wyprawy, jej tragicznego przebiegu oraz procesu sądowego i kolejnych etapów poszukiwania ofiar lawiny. W zgodzie z prawdą pozostała także liczba uczestników górskiej eskapady (11-osobowa grupa: dziewięciu uczniów i dwóch nauczycieli), liczba ofiar (siedmiu uczniów i nauczyciel) i ocalonych (dwóch uczniów i nauczyciel geografii, pomysłodawca i organizator wycieczki). Koncepcja telewizyjnego cyklu umożliwiała natomiast zastosowanie pewnych odstępstw od wiernego kopiowania autentycznych zdarzeń. W ramach tego marginesu wolności reżyser zdecydował się na wprowadzenie dwóch dodatkowych wątków fabularnych, które nie miały pokrycia z rzeczywistością pozaekranową. Pierwszy dotyczył związku uczuciowego głównego bohatera - Wojtka, z inną uczestniczką wyprawy - Olą. Z przebiegu akcji wynika, że chłopak, chcąc pomóc swojej sympatii w górskiej wędrówce, stracił szansę na uratowanie samego siebie, ponieważ gdyby wspinał się w czubie stawki, razem z kolegą - Błażejem, którego ominęła lawina, też by zapewne ocalał. Drugi z wątków odnosił się do konkursu muzycznego dla młodych debiutantów, w którym z powodzeniem wzięli udział dwaj główni bohaterowie filmu: Wojtek i Błażej. Niestety, w wyniku tragicznych wydarzeń ich sukces nie został przypieczętowany nagrodą. Wprowadzone zmiany w żaden sposób nie deprecjonowały opowiadanej historii, a ich głównym celem było spotęgowanie dramaturgii i podkręcenie emocji wynikające z prostego mechanizmu współczucia i żalu, które widz miałby odczuwać, śledząc losy niedorosłych i jakże sympatycznych bohaterów.

W filmie Radosława Dunaszewskiego nieścisłości i odstępstwa na płaszczyźnie fabuły mieściły się, jak w poprzednich produkcjach, w odgórnie zaplanowanej formule filmowej franczyzy, czyli telewizyjnego cyklu „Prawdziwe historie”. Pod rozpoznawalnym logo niezwykle przekonująco prezentował się nośny temat katastrofy górniczej z udziałem Zbigniewa Nowaka, opracowany w „egzotycznej” scenerii Górnego Śląska i z przejmującą historią jego rodziny. Potwierdzenie w faktach znalazły takie wątki, jak: sam wypadek i jego okoliczności, akcja ratunkowa oraz relacje protagonisty z żoną i córką, oparte na bezwarunkowej i głębokiej miłości, a także - istotna z punktu widzenia filmowej fabuły - obietnica złożona najbliższym, że nigdy nie podejmie pracy pod ziemią. Wątek ten stał się jednocześnie polem do 
skonstruowania dodatkowego i niezgodnego z prawdą konfliktu między Zbyszkiem a jego ojcem, weteranem górnictwa, który deprecjonował pracę w kopalni na powierzchni. Z gruntu fałszywie brzmią natomiast nieścisłości pojawiające się w gwarze śląskiej oraz w drobnej faktografii, na przykład informacja o zarobkach na kopalni oraz że wypadek wydarzył się 1300 metrów pod ziemią, w rzeczywistości było to 1030 metrów. Dodatkowym wątkiem są ponadto akcje strajkowe podejmowane przez górników postulujących zwiększenie ich bezpieczeństwa pod ziemią. Wynika to zapewne z faktu, że kilka miesięcy później w stosunku do czasu akcji, w kopalni Halemba zginęło tragicznie 23 górników.

Jak wskazuje Mirosław Przylipiak, analizując kino stylu zerowego, powszechną regułą w tego typu filmach jest upraszczanie akcji i kumulacja zdarzeń oraz operowanie prostymi i łatwo zrozumiałymi emocjami[7]. Film Dunaszewskiego zdaje się hołdować tej regule wielokrotnie. Dla przykładu warto wymienić kilka charakterystycznych zabiegów. Najistotniejszą rolę, obok postaci Zbyszka Nowaka, odgrywa jego córka, tytułowa Laura, która w filmie ma 8 lat i przystępuje właśnie do I Komunii Świętej; w rzeczywistości była dwa lata młodsza. W tym czasie zapada także na groźną chorobę serca i czeka ją nieuchronna operacja; w rzeczywistości miała problemy z mięśniami. I w końcu motywacje głównego bohatera. Zbigniew Nowak przetrwał pod ziemią, oczekując na ratunek, cztery doby. Po wyjściu na powierzchnię tłumaczył, że tym, co trzymało go przy życiu przez tak długi czas, były urodziny jego żony, które wspólnie zaplanowali. W filmie uwolnienie górnika pokryło się w czasie z operacją córki, której mogła nie przeżyć. Oczywiście, wszystko kończy się szczęśliwie, a całości dopełnia sielski obrazek rodziny podziwiającej wypuszczone w niebo gołębie, kojarzone nieodparcie $\mathrm{z}$ folklorem śląskim i symbolizujące nieograniczoną niczym wolność.

Widowisko telewizyjne
„Prawdziwe Historie” - jak brzmi zachęcający tytuł telewizyjnego cyklu - operują atrakcyjnymi wątkami fabularnymi, korzystając z zasobu nagłaśnianych przez media tematów, czyli powszechnie znanych, dramatycznych historii, które wydarzyły się naprawdę. Kluczowe w nazwie tego cyklu jest określenie „prawdziwe”, przekierowujące uwagę widza do sfery faktów. Jak pokazują poszczególne tytuły „Prawdziwych Historii" i co w pewnej mierze wybrzmiało w powyższych rozważaniach, to bardziej zabieg marketingowy niż pokrycie z rzeczywistością. W przypadku analizowanych filmów można raczej mówić o realizowaniu formuły fabularnego kina komercyjnego $\mathrm{z}$ wykorzystaniem narzędzi filmowego dokumentu i związanych z nim stylizacji.

Producenci założyli, że będą to filmy stricte dla telewizyjnego odbiorcy, wychowanego na poetyce popularnych seriali i telenoweli. Jak stwierdziła Krystyna Lasoń, producentka cyklu, poszczególne jego

[7] M. Przylipiak, Kino stylu zerowego. Z zagadnień estetyki filmu fabularnego, Gdańsk 1994, s. 144 i nast. 
tytuły miały funkcjonować na kształt prasy kolorowej, zamieszczającej na swoich łamach tak zwane historie z życia wzięte, w których sam fakt, że wydarzyły się naprawdę, wywoływał emocje u czytelników[8]. W przypadku widowiska filmowego w grę wchodziły dodatkowe atrakcje, na przykład obsada aktorska. Reżyserzy zaangażowali do głównych ról aktorów występujących w serialach emitowanych aktualnie na szklanych ekranach, nierzadko były to gwiazdy rodzimej kinematografii: Witold Dębicki, Gabriela Muskała, Piotr Jankowski, Artur Dziurman (Krzysztof), Edyta Olszówka, Marcin Perchuć, Przemysław Sadowski, Paweł Królikowski, Olga Frycz, Antoni Królikowski (Cisza), Sonia Bohosiewicz, Krzysztof Respondek, Marian Dziędziel, Anna Seniuk (Laura) [9]. Istotną rolę odgrywała również muzyka. Do jej napisania zatrudniono uznanych kompozytorów, z niemałym doświadczeniem w branży filmowej. Znamiennym dla tego typu kina jest uatrakcyjnianie widowiska filmowego wieloma muzycznymi kompozycjami, zazwyczaj jako powracający lejtmotyw, budujący atmosferę i dramaturgię, niekiedy także jako gotowe piosenki, napisane specjalnie dla filmu lub powszechnie znane i lubiane przez odbiorców. W przypadku omawianego cyklu możemy mówić o kilku odmiennych tendencjach. W filmie Dariusza Twaroga rolą muzyki było przede wszystkim budowanie napięcia i wywoływanie emocji, a także tworzenie atmosfery niebezpieczeństwa i tajemnicy, zgodnie ze specyfiką gatunku (film sensacyjny z elementami political fiction) i dynamiką opowiadanej historii[10]. Reżyser Laury powierzył skomponowanie muzyki artystom z zespołu Motion Trio, niezwykle utalentowanym akordeonistom o międzynarodowej sławie, którzy na użytek filmu napisali wpadający w ucho lejtmotyw, brzmieniem przypominający melodie wywodzące się z Górnego Śląska; nomen omen akordeon jest tradycyjnym instrumentem tego regionu. Jeszcze inaczej funkcjonowała muzyka w Ciszy Sławomira Pstronga. Film wzbogacono trzema piosenkami zespołu Dżem: Modlitwa III, Złoty paw, Mała Aleja Róż. Każda z nich koresponduje z logiką zdarzeń i stanami emocjonalnymi bohaterów, mówiąc o stracie i walce z nią, o samotności i tęsknocie; w każdej też na plan pierwszy wysuwa się przygnębienie, płacz i ból, każda przybiera ton rockowej ballady, z przejmującym brzmieniem oraz melodią wywołującą smutek i skłaniającą do refleksji. W finale filmu napisom końcowym towarzyszy jeszcze jeden utwór muzyczny. To kompozycja zatytułowana Tyski oldschool autorstwa Szymona Lenartowicza, jednego z autentycznych uczestników tragicznej wyprawy na Rysy. Licealista stworzył rapową przeróbkę znanego przeboju Powróćmy jak za dawnych lat Jerzego Jurandota i Henryka Warsa. Utwór ten został ograny w filmie na dwa sposoby: jego autorstwo przypisano głównemu bohaterowi - Wojtkowi,

[8] <https://www.tvn.pl/aktualnosci/prawdziwe-historie-oficjalna-strona-stacji-tvn,238988,n.html> [dostęp: 18.04.2019].

[9] W kolejnych częściach cyklu wystąpili również: Magdalena Walach, Bartłomiej Topa, Maciej Musiał,
Anna Przybylska, Szymon Bobrowski, Krzysztof Kiersznowski, Katarzyna Maciąg, Michał Żebrowski itd. [10] Muzykę do filmu Krzysztof skomponował Paweł Lucewicz, autor wielu kompozycji napisanych dla produkcji telewizyjnych. 
i zbudowano na nim osobny, fikcyjny wątek fabularny. Wojtek wraz z kolegą, Błażejem, zgłosili tę kompozycję do konkursu i zwyciężyli. Niestety, wskutek wypadku nie mogli odebrać nagrody, ale płyta z tym utworem stała się interesującym rekwizytem, przedłużającym symbolicznie obecność protagonisty na ekranie.

Podobnie jak przy rekonstrukcji tematu, tak i w sferze zabiegów formalnych wyraźnie zaznaczyła się wśród autorów tendencja do uwiarygodniania historii w diegezie filmowej. Na płaszczyźnie fabularnej przejawiało się to głównie w dochowywaniu wierności najważniejszym faktom przy jednoczesnym uruchamianiu marginesu wolności w rozpisywaniu wątków pobocznych i budowaniu konfliktów między bohaterami, co miało służyć przejrzystości narracji, kumulowaniu zdarzeń i potęgowaniu dramaturgii. Powstawały w ten sposób dzieła o wyraźnie sprofilowanym charakterze, noszące znamiona widowiska telewizyjnego $i$ adresowane do masowego odbiorcy. Wpisywały się one w ten schemat również pod względem formalnym, wykazującym dążenie do eliminacji wszelkich złożoności i niejasności w zakresie dramaturgii, narracji, budowy czasu, przestrzeni i postaci[11]. Mając to na uwadze, autorzy poszczególnych części cyklu świadomie i z premedytacją wyznaczali w swoich filmach określoną perspektywę opowiadania, której głównym celem było wskazanie postaci wiodących i takie rozbudowanie ich ekranowych wizerunków, by widz mógł w jak największym stopniu zidentyfikować się z nimi i wspólnie przeżyć dramatyczną przygodę. Zabieg ten porządkował również i hierarchizował poszczególne wątki fabularne i dynamizował tok opowiadania. W Ciszy do momentu wypadku postacią centralną jest Wojtek, sympatyczny licealista na progu dorosłości, potem funkcję tę przejmują jego rodzice i siostra, ale przede wszystkim matka, która nie może pogodzić się z jego śmiercią. W Laurze owo zawężenie perspektywy jest najmniej widoczne, bowiem akcja toczy się równolegle głęboko pod ziemią, gdzie przebywa uwięziony przez żywioł Zbyszek, oraz na powierzchni, gdzie trwa akcja ratunkowa i rozgrywają się burzliwe perypetie rodziny Nowaków. Dla odmiany w filmie Krzysztof zabieg ten sprawdza się znakomicie. Cała historia opowiadana jest z punktu widzenia siostry tytułowego bohatera - Doroty, która postawiła sobie za cel odnalezienie brata, a po jego śmierci postanowiła odnaleźć i ukarać sprawców jego porwania i morderstwa.

Innym formalnym zabiegiem, wywodzącym się z kina komercyjnego, głównie amerykańskiego, była zasada, której sformułowanie przypisuje się Antoniemu Czechowowi, głosząca, że pokazana w pierwszym akcie strzelba musi wypalić w trzecim. W praktyce przypomina to zasady konstrukcji zagadki kryminalnej - widzowi dostarczane są wszelkie przesłanki potrzebne do odgadnięcia przebiegu wątków fabularnych, ale są one wprowadzane na ekran tak, by ich właściwa rola pozostała niejasna aż do nadejścia właściwego momentu[12]. Nierzadko

[11] Zob. M. Przylipiak, op.cit., s. 147-148.
[12] Wspomina o tym również Mirosław Przylipiak, ibidem, s. 149-150. 
jest to po prostu filmowy rekwizyt, który w pierwszym kontakcie nie zwraca na siebie szczególnej uwagi, nabiera znaczenia dopiero w trakcie rozwoju akcji. Znakomitym tego przykładem jest kartka papieru $\mathrm{z}$ filmu Laura, na której Zbyszek narysował swojej córce schemat podziemia kopalni, czyli miejsca jego codziennej pracy. Rysunek ten w przełomowym momencie stał się ostatnią szansą na odnalezienie uwięzionego pod ziemią górnika, wcześniej był mało istotnym rekwizytem w jednej ze scen dialogowych między ojcem i córką.

Rola rekwizytów na tym się nie kończy. Pełnią one także funkcje magiczne - jako przedmioty symbolizujące w efektowny sposób pewne nadprzyrodzone siły lub telepatyczne więzy między bliskimi sobie osobami. Taka niezwykła więź łączy matkę z synem w filmie Cisza - kobieta zawsze odczuwa pewien niepokój, gdy synowi dzieje się krzywda. Dodatkowo w momencie zejścia lawiny w kuchni nagle bez powodu cichnie radio, co ze zdziwieniem obserwuje matka Wojtka. Identyczny zabieg zastosował w swoim filmie Radosław Dunaszewski. W chwili tąpnięcia na kopalni maskotka na łóżku szpitalnym tytułowej bohaterki samoistnie zaczyna grać, sygnalizując wypadek Zbyszka. Maskotkę tę pluszowego kwiatka - Laura otrzymała od ojca w wesołym miasteczku. W Krzysztofie Dariusza Twaroga w ów schemat wpisuje się krótka scena z udziałem Doroty, która podczas porwania brata w nocy nagle zrywa się ze snu zbudzona przykrymi przeczuciami jakiejś tragedii. Można śmiało powiedzieć, że tego rodzaju zabiegi stanowią pewien lejtmotyw, znak rozpoznawczy całego cyklu i podobnie jako jego nazwa i logo wpisują się w koncepcję filmowej franczyzy.

Na koniec pozostaje do omówienia jeszcze jedna kwestia - relacji między prawdą autentycznych zdarzeń a ekranową fikcją. Dla fabuły było to zagadnienie kluczowe, jako zabieg formalny jest raczej mniej lub bardziej udaną próbą pogodzenia powinności dokumentalistycznych z kreacyjnymi. Innymi słowy - chodzi z jednej strony o uwiarygodnienie przedstawianych zdarzeń o proweniencji faktograficznej, z drugiej o stworzenie atrakcyjnego widowiska telewizyjnego. W poszczególnych częściach „Prawdziwych Historii” zastosowano rozmaite rozwiązania tego problemu. Dla zagadki kryminalnej o zasięgu ogólnopolskim nasuwającym się samoistnie pomysłem było wykorzystanie w filmowej diegezie stylizowanych na autentyczne telewizyjnych przekazów imitujących programy informacyjne stacji TVN. W jednym $z$ nich pojawia się Bogdan Rymanowski, dziennikarz tej stacji, który przeprowadza wywiad z Władysławem Orłowiczem, czyli postacią fikcyjną z filmu Dariusza Twaroga, którą gra Witold Dębicki. W podobnych rolach występują jeszcze inne znane dziennikarki TVN: Brygida Grysiak i Renata Kijowska. W Laurze zastosowano inny zabieg. Na ekranie $\mathrm{w}$ przełomowym momencie filmu pojawia się na krótko sam Zbigniew Nowak, ale nie ten odgrywany przez Krzysztofa Respondka, lecz postać autentyczna, mężczyzna, który faktycznie brał udział w tragicznych wydarzeniach w kopalni Halemba. Jest to swego rodzaju sygnał, oczywiście dla wtajemniczonych widzów, że cała dramatyczna historia zakończy się 
jednak happy endem[13]. Materiałem faktograficznym, którym posłużył się Sławomir Pstrong, były natomiast fotografie. W napisach końcowych na ekranie pojawiają się fotosy autentycznych ofiar lawiny w Tatrach, ośmiu licealistów z Tychów, oznaczonych jedynie imionami: Justyna, Ewa, Szymon, Przemek, Artur, Andrzej, Łukasz i Tomek. W ten sposób widz ma okazję poznać bliżej bohaterów filmu, ich rzeczywistych pierwowzorów; ta osobliwa prezentacja ma dodatkowo mocny wydźwięk emocjonalny. Nieco słabiej oddziałują na widza fotografie stylizowane na autentyczne, spreparowane na kształt tych, które wykonał podczas wyprawy jeden z jej uczestników - Artur Regulski. W filmie autorem tych zdjęć jest główny bohater - Wojtek Domagała, a twarze na nich zarejestrowane zdradzają oczywiście aktorów odtwarzających poszczególne role, a nie autentycznych członków wyprawy na Rysy.

Jak zatem widać, telewizyjny cykl „Prawdziwe Historie” to interesująca propozycja programowa współczesnego kina komercyjnego. Sytuuje się na pograniczu filmowego dokumentu i atrakcyjnej odmiany kina fikcjonalnego. W specyficznych okolicznościach może być traktowany jako produkt handlowy, ale nie tylko w znaczeniu filmowej produkcji i dystrybucji, lecz zdecydowanie szerzej - jako rozpoznawalna marka na rodzimym rynku kinematograficznym, zwierająca wszystkie elementy branżowego know-how, a także istotne i powtarzalne cechy stylu filmowego, który gwarantuje jednocześnie sukces frekwencyjny i finansowy. W pewnym sensie zatem zjawisko to można rozpatrywać w kategoriach filmowej franczyzy, oferującej twórcom, najczęściej początkującym, sprawdzony patent na biznes w postaci spójnego cyklu telewizyjnego, ale także dającej możliwość bezpiecznego debiutu pełnometrażowego oraz przestrzeń do twórczych, i nie tylko, poszukiwań. 